\title{
O símbolo Império em Paul Tillich e a ameaça autodestrutiva da sociedade angolana no romance " $O$ cão e os caluandas" de Pepetela
}

\author{
Natanael Gabriel da Silva**
}

\section{RESUMO}

O presente artigo procura problematizar a leitura que Pepetela faz sobre a sociedade angolana em "O cão e os caluandas", a partir da Teologia da Cultura e as ambiguidades da vida, tendo como referencial o símbolo Império desenvolvido por Paul Tillich. O registro do símbolo Império no referido romance de Pepetela é um caminhar pelo cotidiano de Luanda, sob o regime de um Estado controlado por um partido único. Tal situação resulta, com enrijecimento institucional por meio da burocracia monolítica em corrupção, fragmentação, desumanização e ameaça à integração, manifestado na manipulação e distorção do socialismo, identificado como "esquemático" por Pepetela. Sob a voz profética, o romancista narra a vida, as suas contradições, falta de sentido, descaminhos e sonhos recrudescidos por uma tentativa de antecipação política da vida idealizada, ou vida sem ambiguidade, antecipada e demônica, como aponta Tillich. Palavras-chave: Paul Tillich, Pepetela, Angola, história, autointegração, autocriatividade, autotranscendência, Império, utopia.

\section{THE EMPIRE SYMBOL ACCORDING TO PAUL TILLICH}

AND THE SEF-DESTRUCTIVE THREAT'S OF THE ANGOLAN SOCIETY IN THE NOVEL "O CÃO E OS CALUANDAS", BY PEPETELA

\section{ABSTRACT}

This article problematize Pepetela's reading of Angolan society in the novel "O cão e os caluandas", having the Theology of Culture and the

* Este trabalho é uma ampliação da comunicação apresentada no $24^{\circ}$. Seminário em Diálogo com o Pensamento de Paul Tillich, realizado nos dias 06 e 07 de junho 2018.

** Doutor em Ciências da Religião, atualmente professor na Universidade do Estado de Mato Grosso, Campus de Juara. 
of life's ambiguities as the main reference for the Empire symbol developed by Paul Tillich. The registration of the Empire symbol in Pepetela's novel is a walk through Luanda's daily life, under the rule of a State controlled by a single party. This situation results, with institutional hardening through the monolithic bureaucracy, in corruption, fragmentation, dehumanization, and threat to integration, manifested in socialism manipulation and distortion, identified by Pepetela as schematic. Under a prophetic voice, the novelist recounts life, its contradictions, meaninglessness, misguidedness, and dreams that have been intensified by an attempt at political anticipation of the idealized life, or life withour ambiguity, anticipated and demonic, as Tillich points out.

Keywords: Paul Tillich, Pepetela, Angola, history, self-integration, self-creativity, self-transcendence, empire, utopia.

O que é que eu posso fazer - um simples cantador das coisas do porão? (Deus fez os cães da rua pra morder vocês que sob a luz da lua, os tratam como gente - é claro - a pontapés.)

Belchior

... pois a história é a dimensão em que o novo está sendo criado.

Tillich

\section{Introdução}

Este artigo pretende pontuar a possibilidade da leitura das obras de Pepetela a partir de Paul Tillich. O texto "O cão e os caluandas" é tomado de forma exemplar e, de certo modo, aleatória. Isto quer dizer que a pretensão não é analisar a obra pepeteliana sob um olhar fatiado e de seleção arbitrária. A temática apresentada no romance escolhido é espraiada nas obras do romancista que dialoga de maneira transversal com questões políticas, sociais, econômicas e culturais relativas ao período pós-colonial em Angola. ${ }^{1} \mathrm{O}$ tempo histórico e contemporâneo

\footnotetext{
1 Algumas datas importantes para fins deste trabalho: 1941 - Nasce Artur Carlos Maurício Pestana dos Santos; 1969 - Pepetela é recrutado para a luta armada, vai para Cabinda e torna-se responsável pela área da Educação (Pepetela é pestana em umbundo, nome de guerra); 1970 - Em Cabinda, Pepetela entra em ação de combate pela primeira vez como jornalista da rádio do MPLA; 11 de Novembro de 1975, as três independências concomitantes em Angola: República Popular de Angola (Luanda, MPLA - apoiado
} 
do autor oferece uma propositura discursiva testemunhal que emerge nos escritos de forma tanto dramática, como cômica e, sem dúvida, poética, irônica, desafiadora e livre. A imersão histórica do autor como observador participante é um desvelamento dos dramas, traumas e tramas da sociedade angolana, (quase) hermética.

Leituras do romancista angolano em uma perspectiva histórica já têm sido objeto de uma vasta produção acadêmica. O mesmo não é possível afirmar quando se trata de uma hermenêutica sob o enfoque da religião e da literatura. Trata-se de um campo ainda a ser academicamente problematizado.

Tal diálogo poderia ser iniciado com o discurso tido como profético em Pepetela. Não vamos fugir disso, e sem dúvida seria um bom começo, embora restrito. Há mais de religioso que pode ser pinçado nas obras do romancista angolano do que sua voz de condenação ao sistema. Em "O quase fim do mundo" (2010), por exemplo, pode-se indagar pela recriação e a reconstrução da vida a partir da atual cultura africana. "A geração da utopia" (2013) e sua distopia, outro exemplo, problematiza a sociedade perfeita, escatologicamente esperada, não concluída e destruída, como uma terra desprometida. De certo modo, e de modo certo, nos textos de Pepetela não faltam elementos religiosos, espaços religiosos, personagens com crenças e ética contrária ao discurso pretendido, ritos de passagem como na enigmática e inigualável obra "Muama Puó" (2016b), e de ordens religiosas promotoras e participantes da escravatura, como apresentadas em "A gloriosa família” (2016a).

São apenas exemplos.

pela União Soviética e Cuba), República Popular e Democrática de Angola (Ambriz, FNLA - apoiada pela República Democrática do Congo), República Democrática de Angola (Huambo, UNITA - apoiada pelos Estados Unidos e África do Sul); 1976 - Pepetela torna-se vice-ministro da Educação do primeiro governo pós-colonial e também presidente da Comissão Nacional para a Unesco; 27 de Maio de 1977, tentativa de golpe de Estado em Luanda por Nito Alves, luta pela radicalização negra, contra a inclusão de mulatos e brancos no poder, e com aprofundamento das reformas socialistas - a tentativa é violentamente reprimida; 10 de setembro de 1979 - morre Agostinho Neto e é sucedido por José Eduardo dos Santos, que ficará no poder até 2017; 1985 - Pepetela lança "O cão e os caluandas"; 1992 - Eleições multipartidárias. A UNITA, liderada por Savimbi, não aceita o resultado e os conflitos recomeçam; 22 de Fevereiro de 2002 - Jonas Savimbi é morto na província do Moxico. Fim do confronto bélico. 
Este artigo, porém, não tratará de um traço religioso específico a ser analisado em algum texto de Pepetela, como tomado de forma direta, quer pelo discurso metafórico, quer pela análise de algum evento no qual a religião se apresente objetivamente narrada. Antes, pelo caminho apontado por Tillich em sua teologia da cultura, a possibilidade de supressão das ambiguidades da vida e o inevitável recrudescimento da vivência, sob o símbolo do Império (2014, p. 774ss), serão os instrumentos hermenêuticos assumidos como referencial teórico, na tentativa de compreender o drama da sociedade angolana no período pós-colonial com o esfacelamento da utopia, ou na emergência da distopia, nos (des)caminhos da tradição e cultura negra, encontradas e perdidas, sob a supressão e ausência de uma força autocriativa e dinamizadora da história, implementada por um "socialismo esquemático".

\section{0 símbolo império e a supressão das ambiguidades da vida}

Paul Tillich, assim como outros interlocutores de sua época, se apropria de expressões utilizadas pela tradição e as atualiza, emprestando-lhes novos significados. Deste modo a ambiguidade em Tillich, longe de ser equivocidade, assume na quarta e quinta partes de sua Teologia Sistemática, ou seja, no terceiro volume, o sentido de aproximação e distanciamento, pertencimento e não pertencimento, o que é e o que ainda não é, ruptura e unidade rompida, dependência e singularidade, e assim por diante.

Frederico Pieper (2017, p. 263) mostra que a ambiguidade em Paul Tillich é fundamentada na relação entre essência e existência: "Enquanto a essência nos mostra aquilo que deveríamos ou poderíamos ser, a existência nos revela o que efetivamente somos." Ou seja, em seu estado de alienação do ser de seu fundamento essencial, essência e existência encontram-se distanciadas, mas se pertencem, e a arena onde a ambiguidade em decorrência da separação se manifesta é a vida. A vida, portanto, é ambígua, como aponta Paul Tillich:

Mas a vida está fundada na perda da inocência sonhadora, na autoalienação do ser essencial e na mescla ambígua de elementos essenciais e existenciais. Na vida como é efetivamente, encontramos moralidade separada com suas ambiguidades, cultura separada com suas ambiguida- 
des e religião separada com suas profundas ambiguidades. É destas que devemos nos ocupar agora. (2014, p. 553).

A vida é ambígua e se dá na história. Fica assim evidente que as limitações decorrentes de uma interpretação exclusivamente a partir do ser lançado no mundo, ou seja, uma compreensão do ser apenas pelo viés existencial, como fizera o jovem Martin Heidegger (1967), é insuficiente por ser limitadora. A dimensão pura ou prioritariamente existencial, sem levar em considerarão o ser em seu fundamento essencial, limita a condição humana, prossegue Pieper (2017, p. 264), cujas contradições, ou ambiguidades, apenas a expressão "vida" poderia suportar.

De fato, a escolha do termo vida por Tillich se dá em razão de ser esta dinâmica, aquela que se mostra, se revela, mas também se oculta. $\mathrm{O}$ ser humano é finitude, mas também infinitude, isto é, ao mesmo tempo em que é, tem a impulsão para o que será, na busca do reencontro com o seu fundamento. Enquanto a vida presente é conduzida pela ambiguidade, o ser humano, como ser, é portador de uma preocupação que seria última, que é desejar, aspirar, e rumar para uma vida sem ambiguidade, cuja "ocorrência" se dará no que Tillich chama de símbolo do "Reino de Deus". Este seria um estado de perfeição e que não pode ser antecipado como conquista existencial, sem que a vida seja destruída. O ser humano que "caminha" para a infinitude, tem a liberdade de ser o que é, mas o destino o limita. Enquanto a liberdade é potencialmente plena, o destino é o resultado das escolhas desta liberdade. Trata-se de uma dinâmica que causa movimento, as escolhas da liberdade se concretizam em uma realização, que operam a possibilidade de novas escolhas e assim por diante. Não é possível destruir a liberdade, sem destruir o destino. Liberdade e destino se pertencem e ao mesmo tempo se distanciam.

Deste modo, não é uma questão de solucionar as ambiguidades ou tentar superá-las na condição existencial, porque isto seria submeter o essencial ao existencial. Esta "solução" daria a primazia à existência. O essencial, então, se perderia, e o humano, deixaria de ser humano, e a vida, por conseguinte, não seria vida. Nas condições ameaçadoras da existência, as ambiguidades polarizam, sem síntese, e geram o movimento chamado de vida. Com outras palavras, em Tillich, as ambiguidades dão à vida, nas condições de existência, a condição de ser vida. 
Quando se trata de história, ou coletividade, vida comunal, o princípio da ambiguidade permanece o mesmo. A vida se dá na história, e se a vida é ambígua, a história também o é. Para Tillich as ambiguidades da vida na história são impulsos à autointegração, autocriatividade e autotranscendência (2014, p.767). A autointegração na história, assim como na vida em sua individualidade, é promovida pela própria história centrada, portanto um para si indivisível. Não há um rompimento, pois a história passada torna-se parte da subsequente; não é a mesma, mas também não é outra. O movimento é um sempre para frente e, assim como na ambiguidade da vida e no ser dotado de potência, a história também se desloca, mantendo o seu centro integrador do que é para o que será ou está sendo. Ela se mantém história, por conta da memória e das tradições como centro para o qual tudo converge e, ao mesmo tempo, é superada por meio da autocriatividade.

A autocriatividade na história é a potência de reinvenção da própria história. A história sempre busca o novo, o para onde. Fica claro que tal movimento não pode ser feito sem a centralidade, a qual é mantida na história e ao mesmo tempo "sofre" o processo de atualização. Não é possível destruir o fundamento histórico, sem destruir a história. A centralidade estará presente no novo que dela se apropria, mas também a nega. A autointegração é liberada pela autocriatividade, que por sua vez resiste à autointegração e por ela é limitada, mas concomitantemente a inova.

A autotranscendência, o terceiro impulso apontado por Tillich, não seria apenas o movimento na passagem da autointegração pela autocriatividade em busca do novo, embora a autotranscendência não esteja ali excluída. Se a autotranscendência fosse apenas o movimento que ocasionasse a apropriação e modificação da autointegração pela autocriatividade, a história estaria circunscrita à finitude. A história não seria superada em sentido e o símbolo "Reino de Deus" estaria irrecuperavelmente perdido. A história ficaria enclausurada, estagnada, e a própria vida se perderia. Se assim o fosse, só seria possível dialogar a partir da existência, não haveria vida sem ambiguidade, porque não haveria superação da finitude. Ou seja, a autotranscendência, reservada apenas à dinâmica da autointegração à autocriatividade, seria tão somente horizontal; não superaria a vida, por conseguinte nem a 
própria história. Para ir além da finitude, que pergunta pela vida sem ambiguidade, a potencialidade se dirige para a superação desta mesma finitude, e a autotranscendência assume a possibilidade de se dar como busca de superação da própria história.

A autotranscendência nos remete ao problema do divino e do demônico em Paul Tillich. O exemplo que Tillich busca na história é do Império Romano como demônico (2014, p. 560). O demônico em Tillich é quando o que é portador de finitude evoca para si a condição de infinitude. Se por um lado a autotranscendência fosse limitada ao movimento da autointegração à autocriatividade, a história seria destruída. Por outro lado, se o que está para além da história fosse antecipado, dando ao finito a condição de infinitude, segundo Tillich, estaríamos diante do demônico. Isso é o mesmo que alcançar, por antecipação, a vida sem ambiguidade na tentativa de dar cabo das ambiguidades da vida. Ora, são as ambiguidades que fazem da vida, vida, e o demônico ao invés de destruir a autotranscendência, acaba por distorcê-la; torna o finito como se infinito fosse. Seria como estabelecer o limite para a esperança e a fixação no tempo existencial da "solução" às condições ameaçadoras da existência.

$\mathrm{Na}$ história, interpretar determinado movimento como ápice ou o fim da história, como se exatamente naquele momento o ideal tivesse sido conquistado ou construído, é pródigo dos sistemas absolutistas e ditatoriais. Este ideal tido como realizado só é possível ser assim interpretado se a utopia se der como fato. Ora, o fim idealizado não precisa ser reformulado, necessita apenas de uma única linguagem de consolidação. Com outras palavras, se torna monolítico. As forças renovadoras da história são banidas, perseguidas, caladas. A autocriatividade se perde. O novo momento declara que o fim está concebido, fora realizado na história. Chegara o limite e a fronteira do "além de" está antecipada, metaforicamente, aconteceu o verdadeiro "céu" e "paraíso". Qualquer que seja a situação, promovida por sistemas políticos, religiosos, ou qualquer outro, ao perder (ou autoritariamente fazer calar em nome de uma verdade) a dialética criativa, os sistemas recrudescem e acabam por desaparecer em função dos males combatidos anteriormente pelo próprio sistema. O novo acaba por repetir os males havidos no sistema anterior. Não importa se tal poder é político, eclesiástico, econômico, 
de uma ditadura capitalista ou operária, o resultado para Tillich será sempre o mesmo. No demônico há, portanto, uma tentativa de antecipação plena da vida sem ambiguidade para o existencial, com a supressão dos impulsos dinamizadores da própria história. Há o recrudescimento. No recrudescer e no engessamento da criatividade, o Império entra em colapso.

Assim Império, para Tillich, é o símbolo metafísico que movimenta a unidade política estruturada, dando a esta a atualização utópica. $\mathrm{O}$ Império é a homogeneização que cria uma identidade estática espraiada a toda uma coletividade. Por um lado, o Império surge como um ideário, ou ameaça, de pertencimento e dissolução de um determinado núcleo consolidado, como uma tribo por exemplo. Por outro, a antecipação da finitude como "solução" das ambiguidades da vida, opera a sua paralisação e anuncia a própria morte. A história, como invenção do novo, num dado momento irá recuperar a sua dinâmica. "Nenhum indivíduo e nenhum grupo podem fugir da dinâmica da história para evitar as implicações trágicas da grandeza da história, tal como se expressam no símbolo do Império." (2014, p. 776).

Deste modo, o símbolo Império se dá como um todo que se apropria de um discurso único, como atualização de uma utopia que era pretendida como superação da história contra a qual se combatia. Ao se espraiar, o Império transforma as ambiguidades em objetividade histórica com um único viés. Temas, como "progresso programado", por exemplo, substituem a dinâmica da história em sua construção dialética. Com outras palavras, desaparece a utopia. Seu fundamento é a finitude, com ações para a sublimação da transcendência. $\mathrm{O}$ monolítico subsume a dinâmica. Esta é anulada, assim como a sua criatividade, e as ambiguidades que dão movimento ao processo histórico, desaparecem. Desaparecer tem mais o sentido de sublimação, pois a potência criativa da vida, ressurgirá como fênix por meio da voz profética. Esta tenta recuperar o processo dinâmico. A voz profética, assim, resiste à estagnação substancial, mantida e preservada de forma sacerdotal pelo sistema ou pelos supostos detentores e controladores da história. Com isso, vem a hecatombe, e o Império acaba por sucumbir exatamente por ter mantido, ou desejado manter, ausente a dinâmica criativa. É como se o tempo histórico, parado pela sublimação da dialética, retomasse o seu curso. 
Trata-se o símbolo Império, portanto, como força gregária e "artificial” de um todo concebido, dado como atualização e realização final do tempo histórico. A ambiguidade profética é a inteligência criativa, com fundamento na liberdade e se dá como um excesso ou superação da possibilidade histórica existencial, ou seja, busca a utopia a se realizar no kairós.

Com outras palavras, Tillich compreende que o símbolo Império, ao se realizar na história, tido como estágio final desta, encontra também o seu fim, porque o recrudescimento resiste à inteligência criativa que o originou:

Existem duas tendências contraditórias, uma rumo a um controle totalitário da vida de cada pessoa que pertence a um grupo portador de história e especialmente a um grupo imperial, e a outra rumo a uma liberdade pessoal que alimenta a criatividade. A primeira tendência é fortalecida quando conflitos externos exigem um aumento de poder centrado ou quando forças desintegradoras dentro do grupo ameaçam a própria centralidade. Em ambos os casos a necessidade de um centro poderoso reduz e tende a aniquilar o elemento de liberdade que é precondição para toda criatividade histórica. O grupo é capaz de atuar historicamente por causa de sua rígida centralização, mas não pode usar seu poder criativamente porque suprimiu aquelas potências criadoras que conduzem ao futuro. Somente a elite ditatorial - ou apenas o ditador - é livre para atuar historicamente, e daí as ações, porque estão desprovidas de sentido que pode aparecer somente no encontro de agentes livres, morais, culturais e religiosos, se tornam impulsos vazios de poder, embora frequentemente numa grande escala (TILLICH, 2014, p. 776).

Tillich compreende que a democracia seria a forma política que suporta as ambiguidades, a liberdade criativa e o poder político centrado. Se por um lado o poder centralizado inibe a liberdade criativa que o atualizou, a liberdade criativa, sem o poder centralizado, também é ameaçada pela fragmentação individual. Neste caso, perde-se também a utopia.

O ceticismo de Tillich, quanto à antecipação da utopia, sonho e esperança em sua plenitude na dimensão exclusivamente existencial, até mesmo por meio de uma possível "evolução", é claramente apontado logo na introdução de seu terceiro volume da Teologia Sistemática: 
Bem depois que eu escrevera as seções sobre a vida e suas ambiguidades, tive a oportunidade de ler o livro de Pierre Teilhard de Chardin, $O$ fenômeno humano. Encorajou-me muito saber que um renomado cientista havia desenvolvido ideias sobre as dimensões e processos da vida tão semelhantes às minhas. Embora eu não possa compartilhar de sua visão bastante otimista do futuro... (2014, p. 471)

Posteriormente, reafirma:

Não há humanidade unida na história. Ela certamente não existiu no passado; nem existirá no futuro, porque uma humanidade politicamente unida, embora imaginável, seria uma diagonal entre vetores convergentes e divergentes. Sua unidade política seria a moldura para uma desunião decorrente da liberdade humana com sua dinâmica que a tudo transcende. [...] Enquanto houver história, uma "humanidade unida" é o marco para uma "humanidade desunida". Somente na pós-história poderia desaparecer a desunião, mas este estágio não seria o Reino de Deus, porque o Reino de Deus não é "bem-aventurança animal" (2014, p. 748).

Pepetela compartilha de um cetismo semelhante, embora acredite na força profética, até mesmo em razão de seu discurso. Ao se dar, historicamente, envolto no que Tillich chamara de Império, a pergunta do romancista é uma pergunta que não responde: para onde iremos?

Então, os romances de Pepetela foram escritos sob a dimensão trágica desta distopia. A antecipação do sonho da vida sem ambiguidade como idealização da sociedade perfeita após os longos quinhentos anos de domínio colonial português, a realidade dos agentes da libertação e os caminhos abertos pela trilha política em Angola, seguida à independência de três décadas de lutas internas pós-colonial em uma sangrenta e inexplicável guerra civil, motivada tão somente pela avidez pelo poder e domínio e posse pelos grupos sectários das fontes produtivas: tudo isso forma o background de suas obras. A opção política pelo partido único, ao tempo da publicação de "O cão e os caluandas", é uma crítica ao sistema do qual Pepetela fazia parte na estrutura de governo. Mais que crítica, será preciso, talvez, uma leitura mais ampla de suas obras para um encontro com o grotesco melancólico, sem saída, de uma sociedade que perdera o poder de reinvenção. O que parece aproximar-se de Bakhtin (2010), dele se apropria e o nega, se distancia, se dá como 
melancólico, e o cômico se perde em meio à falta de esperança, ou talvez num falso riso, efetivamente triste.

Vamos ao que Pepetela tem a nos dizer.

\section{A distopia, os caluandas, o cão e os sonhos}

A obra de Pepetela que este artigo pretende estudar, "O cão e os caluandas", é um texto primoroso. Rico em ironia e carnavalesco. É criativo, com capítulos ou crônicas, que podem ser lidos aleatoriamente e registram o cotidiano da cidade de Luanda no final dos anos 80, pouco antes do multipartidarismo ganhar espaço a partir do início da década seguinte. Trata-se do relato de uma sociedade em construção pós-colonial, com libertação ocorrida em 1975, após cinco séculos de domínio português.

"Caluanda" é o luandense, nascido, residente em Luanda, uma cidade-símbolo da transição entre o kimbo (aldeia) e a vida urbana. $\mathrm{O}$ cão é a personagem que irá percorrer anonimamente as ruas desta metrópole ${ }^{2}$. Precisa ser cão, como pessoa sonhadora e simples, um comum, para não ameaçar, passar quase como anônimo ou esquecido e permitir que o cotidiano se torne clarividente, sem que se dê por suspeito, em razão do controle do regime de força e sua espionagem infiltrada em qualquer canto, como medida preventiva e castradora. Anônimo, em termos, pois será chamado de cão, na maioria das vezes, mas também Lucapa, Leão dos Mares, Cupido, Jasão e cão-polícia, a depender do contexto narrado. Contudo, não passava de um cão (ou não). De certo modo se apresenta como um profeta que percorre as ruas, facilita a condução histórica por meio de ações que poderiam ser até consideradas como intervenções cidadãs; aparece e desaparece no anonimato do cotidiano, enquanto a este dá sentido.

Um cotidiano angolano rico, diga-se de passagem. As crônicas de "O cão e os caluandas" formam criativamente uma unidade rompida e fragmentada, por meio de estilos variados. Aparecem em forma de relato e memória dos moradores-narradores, sendo eventualmente

2 Cuja estatística, nos limites dos problemas urbanos de Luanda, com ruas sem nomes e casas sem números, dava conta em 2017 de cerca de seis milhões de habitantes, pouco mais de trinta anos após o lançamento do referido romance. A data, 2017, refere-se ao último ano de minha estada naquela capital. 
substituídos pelo escritor. Neles há conversas internas da burocracia do Estado, Ata de reunião da Comissão Sindical, anúncio de jornal, cartas, peça teatral (esquete), notícia de jornal, trâmite de uma petição administrativa que perpassa os escalões e mesas da referida burocracia socialista, relatório de agente civil de observação e controle, além de um interrogatório. Cada capítulo, contudo, traz em evidência a distopia presente na sociedade angolana; a desorganização social promovida tanto pelo poder, quanto pelo modo de vida popular, cooptada ou não pelo sistema. Pepetela denuncia. Coloca a sociedade angolana no caminho da autodestruição e aponta a presença imposta do "socialismo esquemático", castrador e sem criatividade de se reinventar e, portanto, sem a potência dinamizadora da história.

O texto, na verdade, pode ser considerado como uma coletânea de 22 crônicas. Os capítulos propriamente ditos são 18. Há um epílogo que, pelo conteúdo, pode ser considerado como crônica adicional, assim como os dois últimos episódios, e uma das crônicas tem dois capítulos; outra tem dez, espalhados aleatoriamente entre as demais. Somam-se a estes capítulos uma apresentação, que não é necessariamente um prefácio, e sim uma crônica com vestígios de prefácio. A organização, ou desorganização do texto, ao invés que criar barreiras para a leitura, o tornam fluente, tanto enigmático e misterioso, quanto aberto e criativamente sugestivo. Afinal o cotidiano é múltiplo, plural, desencontrado, contraditório, como deve ser a vida em sua expressão histórica; um mundo urbano aparentemente sem fronteiras, complexo e desafiador.

Alguns pontos fundamentais deste texto de Pepetela já foram mencionados anteriormente, a saber: o contexto urbano de Luanda e o cão que perambula por entre as ruas a revelar a radiografia cultural. Será preciso compreender que o cão fora criado em uma quinta, que ficava nos arredores de Luanda. A narradora da crônica dividida em dez capítulos, que é um fio condutor de todo o texto, trata-se de um diário pessoal. Nele, a miúda menciona a exploração da terra, dos trabalhadores, a produtividade e os mecanismos de obtenção de favores e formas de corrupção a encontrar caminhos por entre a rigidez burocrática do sistema estatal do partido socialista único. Simbolicamente, além do cão e outros animais próprios de uma quinta, a atenção da narradora 
se volta para uma buganvília, que dá o título à crônica em capítulos dispersos dentre os demais.

A buganvília é odiada pelo cão. É verde e de flores roxas, e sua missão parece ser a de sufocar, aos poucos, uma trepadeira que possui baguinhos vermelhos. Flores roxas da buganvília que sufocará a trepadeira vermelha, substituindo o sonho da utopia socialista, pelo próximo distante e desvirtuado colorido, e lhe porá um fim. Deste modo, a utopia é sufocada pela distopia.

No emaranhado da desconexão da vida, contudo, a superação existencial ainda encontrará a (in)existente toninha, para a qual os sonhos extrapolam como busca de um novo e (im)possível sentido. O autor a procura (2014, p. 146) e há um capítulo dedicado à aparição da toninha, cujo título é "No mar anda uma toninha" (2014, p. 53). Entretanto, antes na crônica-prefácio, Pepetela já registrara que a toninha era/é "um ser de espuma, algas como cabelos, que talvez só tenha vivido na minha cabeça. E na do cão, claro.” O capítulo específico sobre a toninha pouco acrescenta sobre sua natureza, mas a coloca no contexto de celebração de um amor infiel, dois apaixonados entregues à intimidade, sendo ela, casada. Na história o cão aparece protegendo a infidelidade contra transeuntes que poderiam passar na praia onde a relação acontecia. Adiante, no epílogo, o cão se depara com a toninha, a avista da praia por entre as ondas a jorrar espumas. O cão passaria a ir ao mesmo local, todas as tardes, na ponta da ilha do Mussulo, onde vira a toninha pela primeira vez. Pepetela, ao encerrar o epílogo, deixa alguns traços narrativos para uma possível (ou não) compreensão, da vida e liberdade da toninha, e a morte no limite da liberdade, onde começa o mar, também onde começa e termina o que há de mais humano no humano: o amor e o traço infiel deste, contraditório, desencontrado, flutuante entre os sentimentos, capaz de negar as virtudes e os valores morais, sem se perder, porque o amor, é o amor. A flutuar entre as ondas, e presenciar o amor, há uma toninha como sonho, uma indescritível abertura à aventura da vida:

Creio que todos, homens do mar, temos uma toninha que só aparece uma vez na vida e que, ao ir-se de vez, nos deixa um vazio no coração. E dá vontade mesmo, quando o Sol morre no mar, ganir para essa toninha que tem algas como cabelos. Ela procura uma ilha, temos de a deixar seguir 
o seu caminho, mesmo que fiquemos na praia a perdê-la morrendo toda a vida. (PEPETELA, 2014, p. 156/7).

A crônica-prefácio (p. 9), que abre o texto como um aviso ao leitor, tem o lugar da utopia e datação futura, como se o texto fosse um olhar para o passado. As cenas narradas, diz Pepetela no início, aconteceram em 1980. O texto foi publicado em 1985, e a crônica-prefácio é datada de 2002. O local da escrita é a imaginária cidade de Calpe, o lugar dos sonhos de "Muana Puó".

No primeiro capítulo propriamente dito de "O cão e os caluandas", titulado "Tico, o poeta" (p. 11), a distopia alcança o jovem comum da geração seguinte à libertação, um vadio improdutivo que se diz intelectual e revolucionário com o seu segundo ano no Liceu; um poeta de um poema só. Tico é a descrição da geração seguinte à emancipação política, um sem destino ou futuro, que perdeu a condição de infinitude. Na crônica, "O primeiro oficial" (p. 19) o romancista explora a corrupção degradante do sistema político fechado, burocratizado, dominado em todos os níveis por esquemas e caminhos para a transposição de barreiras e favorecimentos, no qual a expressão "socialismo esquemático" surge com definição, nos argumentos do primeiro oficial: "Oh, eu também tenho um esquema para a carne, o peixe, as verduras, a roupa... Porque essas lojas oficiais não têm nada. Entro nos tempos, não estamos no socialismo esquemático?” (p. 20) Já no capítulo seguinte, "Luanda assim, nossa" (p. 29), emerge o preconceito protagonizado pelo tribalismo, quando um luandense recebe um bom amigo "apesar de malanjinho". Malanjinho é a referência ao nascido na província de Malanje. Tanto o anfitrião, como o visitante, haviam se envolvido em uma briga coletiva por conta do domínio político em uma igreja protestante, na qual os de Catete, que a haviam fundado, resistem à invasão malanjina, com resistência bíblica: “As gentes do Catete não se deixam pisar, são uns homens bíblicos" (p. 30); homens da luta, da guerra, da força, da negação da ética, do amor e da cidadania por meio da violência assumida e autorizada pela fé. O caluanda ainda resume o pensamento de Karl Marx: "Marx disse: primeiro a barriga, depois as ideias e os sentimentos” (p. 32), não há urbanidade, coletividade, pertencimento ao todo, apenas a individualidade. Malaquias, 
o malanjinho, ao ir embora decide levar o cão que havia entrado sem rumo e presenciara o preconceito expresso no declarado pelo luandense: "Filho de cão racista é racista. Esse cão tem o vírus do ódio negro, da desconfiança do mulato, do respeito ao branco.” (p. 32). É a denúncia do preconceito havido em Luanda. A pergunta que Pepetela deixa sem resposta é: Que sociedade? Que povo? Que futuro? Que utopia? Que coletivo? Que angolanidade?

A crônica seguinte tem por título apenas "Acta" (p. 35), e a tratativa é esta mesma: o registro de uma reunião burocrática e sem sentido, protecionista, mas aparentemente séria e imponente, como mostra das estruturas das fábricas improdutivas pós-colonial, da sociedade que vive e sobrevive por aparências. Em "Anúncio do jornal de Angola” (p. 41) há a melancolia e o abandono de uma viúva, com 40 anos de idade que procura o cão que a deixara e que fora seu único companheiro. A nota, acrescida no jornal, em contraste com o sofrimento da (jovem) viúva, aponta que, a notícia embora parecendo dos tempos coloniais, se referia à atualidade. Ou seja, entre a opressão colonial e o desamparo social no período de libertação, o resultado era o mesmo.

O socialismo esquemático e seu excesso burocrático, inoperância e falta de sentido, é retomado em "O mal é da televisão" (p. 43). No texto, um burocrata inoperante, de um sistema governamental improdutivo e que sobrevivia e vivia de reuniões e mais reuniões onde nada era decidido, joga a fúria da insuficiência e de objetivo de vida contra o aparelho de televisão, e o destrói. É a denúncia de que, afinal, o opressor era consciente, pelo menos em parte, do oportunismo político que não apresentava resultado. Contudo, na crônica seguinte, a acefalia coletiva e ausência completa de qualquer projeto, é substancialmente potencializada, escrita como uma esquete na inversão de Erasmo: "O elogio da ignorância” (p. 63). A organização política na qual a Angola pós-colonial se aventurava era teatral, com personagens que só sabiam contar até quatro por conta do número de caminhões desviados do sistema. O governo é apresentado como uma peça sem roteiro, organização ou finalidade; sequer tinha argumento. No debate, que se fazia na liberdade dos atores, como é na vida, discute-se a formação de um tribunal num julgamento sem sentido, na trilha de Kafka, para no final terminar em festa coletiva regada à cerveja. No "socialismo esquemá- 
tico" tudo se constrói na improvisação, não chega a lugar algum, mas termina na festa da uma grande (e gloriosa) família.

Em "O cão escapa de aparecer no jornal" (p. 73), o estilo é de uma notícia que aparece na primeira página do Jornal de Angola, um tabloide de voz oficial do governo que controla cuidadosamente toda a mídia. Na notícia, o cão acaba por se tornar mais esperto que as Forças Armadas Populares de Libertação de Angola (Fapla), na qual ficam evidentes os desencontros, berço de vaidades, domínio e seleção do que comunicar como propaganda do poder, que sequer dá conta do necessário à segurança. "Ciúmes" é uma crônica em dois capítulos (p. 77 e 85). No primeiro, a narração é o testemunho de uma mulher; no segundo, muito curto, o olhar é do ex-marido. As crônicas registram a vida doméstica, não tratam de questões políticas diretamente, mas da geração seguinte a vivenciar o carnavalesco, o grotesco e surreal a organizar a vida. No caso, o marido é incisivamente questionado entre preferir viver com a mulher ou com o cão. Ele pede tempo para pensar. O texto dialoga pelos meandros de um dos mais importantes mitos angolanos, que é a valorização da família, e o desconstrói pelos caminhos da própria tradição.

Os contrapontos entre fé, pequena burguesia política e os pobres, são cuidadosamente elaborados em "Carnaval com Kianda" (p. 87). O primeiro discurso, na crônica, é na primeira pessoa, logo após a apresentação do escritor-narrador. É o discurso do padre contra os demônios, que são: o carnaval e o anti-Cristo. A personificação do mal, para o pregador, era o cão que havia invadido a Igreja no ato de celebração da Semana Santa. O padre dirige-se ao cão, e coloca, não sei se o cão ou o governo de Angola, talvez ambos, sob o domínio do mal:

E tu, Satã disfarçado de cão, tu que és o anti-Cristo que governa este País, treme, porque o Senhor mandará o raio, a peste, a cólera, os leões, os gladiadores e aniquilará a pobre minoria que te segue no Carnaval e noutras festas bárbaras. (p. 90).

Ao terminar a missa, o povo sai às ruas a desfrutar da festa popular. O primeiro desfile é dos carnavalescos vestidos de preto e vermelho (cores do MPLA e atuais de Angola). O ritmo é fúnebre. A alegoria mostra um poder imperial vestido de forma quixotesca. Por fim, a 
"União Kianda da Corimba", de pescadores, que com a colaboração do cão, mágica e magistralmente se apresenta, sob a cadência da criatividade. Possibilitam a metamorfose da morte em alegria e celebração da vida, e os pescadores se apresentam como voz profética: há esperança?

A análise, ou a radiografia do cotidiano em Luanda por Pepetela, também discute o problema do operariado, na cultura do socialismo esquemático e corrupção generalizada, em todos os níveis e escalas de comando de uma fábrica. Mostra os caminhos burocráticos e seus benefícios que geram a estagnação produtiva, e por aí se vai. Estes são temas tratados em "Lição de economia política" (p. 97). Já em "Regressados" (p. 109), o romancista aborda o problema dos que voltaram, refugiados que se tornaram quando da guerra. Agora são estrangeiros na própria terra. Alguns se aventuram pela criminalidade como única forma de sobrevivência, mas todos são sem nomes na crônica. Estrangeiros não têm nomes, são diminuídos como pessoas, identificados apenas como anônimos numerados, do primeiro ao oitavo, despersonalizados, desconhecidos e excluídos.

Em "Que raiva" (p. 119), Pepetela explora a ineficiência do serviço público, de uma estrutura de organização engessada, desprovida de justiça, acéfala, tanto por deficiência na formação educacional de quem ocupa os cargos, quanto do respeito à ética. O texto é todo formado por memorandos que percorrem a hierarquia. Com a lenta burocracia, perde-se o tempo de alguma ação sanitária urgente (evitar o surto de raiva canina), o documento vai pelos graus superiores da estrutura de comando, um a um. São assinados de maneira ilegível, e sempre, ironicamente, concluídos com letras em caixa alta: "SAUDAÇÕES REVOLUCIONÁRIAS" [...] "ANO DO 1‥ CONGRESSO EXTRAORDINÁRIO DO PARTIDO E DA CRIAÇÃO DA ASSEMBLEIA DO POVO.” Ou ainda a transcrição dos gritos de guerra, próprios dos documentos oficiais na emancipação política: "A luta continua! A Vitória é certa!" No final, a recomendação da punição em face da demora, recai sobre aquele que apontara a necessidade social e se encontrava na função mais baixa do sistema.

A prostituição, como sinal de uma sociedade desumana e decadente, é narrada em "Entre judeus" (p. 129). Um dos pontos de partida de registro dos excluídos é o preconceito: "Mulato é o judeu de Angola." 
(p.130). De excluído a excluído, o narrador dialoga com a prostituta, ou com a quitata-de-luxo, cujos sonhos vão desde encontrar um príncipe encantado ao recebimento de uma simples ternura. Na crônica, Angola é apresentada como uma sociedade apodrecida e sem futuro.

O diálogo subsequente, na crônica seguinte, é do autor com uma personagem em um bar, titulada: "Conversa com um informador pouco cooperativo" (p. 145). Nesta, o autor se depara com um interlocutor que se denomina Xis. O designativo esconde e camufla aquele que gostaria de se manter anônimo frente ao poder público. O informador é o cidadão comum, pouco amistoso, e quer ser bem favorecido em qualquer situação, até mesmo para uma conversa e entrevista, interesseiro, irônico e pouco confiável; é a partir deste cidadão, do povo, que uma nova nação está no caminho, ou descaminho, de sua (des)construção.

Com o salto de um capítulo, que será objeto de análise mais circunstanciada adiante, chegamos ao epílogo (p. 153) e que também é uma crônica. Nela, o cão vai viver na ilha do Mussulo com um pescador, que é o narrador e diz fazê-lo na língua materna, em kimbundo. $\mathrm{Na}$ ilha, o cão se encontra com companheiras e enche o lugar de filhotes. Depois que vira a toninha no mar, o cão vai à ponta do Mussulo e geme baixinho à espera de uma nova aparição, em forma de sonho, quem sabe, outra utopia (p. 156).

Pepetela acrescenta ainda dois capítulos: "Primeiro episódio: onde o autor é obrigado a retratar-se" (p. 159) e "Primeiro episódio: outra versão possível” (p. 165). No primeiro, o cão é visto numa partida de futebol em Cubal, na província de Benguela, ao mesmo tempo em que estava na ilha do Mussulo. A distância entre Cubal e Mussulo é de cerca de mil quilômetros e, em razão da impossibilidade (ou não), o autor libera o leitor e aponta o descaminho pós-colonial:

Qual então o fio da estória? O cão? A toninha? O mar? Luanda? Ou tudo isso e que afinal era a vida boa daqueles tempos pouco depois da independência (anos hoje acinzentados pelos anos), em que a vida estava na pedra de cada muro, no buraco de cada rua, na coragem toda nova das pessoas de olharem para o fundo dum beco sem saída e encontrarem força de sorrir? (PEPETELA, 2014, p. 164). 
Se no primeiro episódio o encerramento é com a morte da escrita, no segundo é a vez do sonho morrer. Assim, o cão retorna à quinta, enfrenta a buganvília que havia tomado todo o muro, cheia de espinhos que o feria enquanto este a atacava. A buganvília é cortada, num único golpe, por um mais-velho. O cão então volta ao Kapossoka, terminal marítimo de passageiros e que dá saída para a ilha do Mussulo. Fica lá, olhando para o mar em seu último gesto à procura de uma toninha.

Fim do romance.

Esta rápida e precária análise das crônicas dispersas, ordeiramente desorganizadas, e colocadas uma ao lado da outra, são uma mostra visceral da sociedade angolana e de sua dramática situação de construção e desconstrução no período pós-colonial. Das narrativas acima, ficou faltando um capítulo, como apontado, para uma aproximação um pouco mais abrangente, como segue.

\section{Um capítulo: “objeto: relatório das ocorrências na bicha do martal"}

O capítulo (p. 139), em síntese, apresenta um agente infiltrado para observar o cotidiano de uma ocorrência em Angola. $\mathrm{O}$ agente infiltrado era, e talvez ainda seja, prática comum em Angola, mantida e patrocinada pelo poder público, no tempo de "O cão e os caluandas", partido revolucionário e único. O objetivo é identificar os possíveis opositores ao regime, e dar-lhes alguma destinação que não seria noticiada, obviamente. Uma boa caricatura da espionagem local é escrita por Pepetela em dois romances específicos, baseados na figura de James Bond. Pepetela cria o seu correspondente grotesco em Angola chamado de Jaime Bunda (2010a, 2010b).

O agente de representação pública, na crônica da fila do Martal, é também o narrador. Ele escreve um parecer em relatório formal, como prática comum dos documentos internos do sistema burocratizado, acerca do que ocorrera numa fila de supermercado (Martal). Num dado momento, na fila, deu-se uma maka (confusão) em face do mujindo (notícia, boato) de que no referido supermercado haveria bacalhau.

$\mathrm{O}$ agente que narra e registra oficialmente o relatório tem por nome Dias, e também assina com o codinome Olho Duro. O texto, como relatório, possui formalmente: A) um relato histórico; B) quatro conclusões 
formais e C) três recomendações para ações futuras. No documento, há uma mostra da preservação da hierarquia rígida instituída pelo regime de partido único. Tal hierarquia e voz de comando, na orientação da linha investigativa, gera a dependência por delegação de superiores de superiores, os quais por sua vez precisam prestar relatórios que serão encaminhados aos que estão acima, numa relação quase infinita. A hierarquia se perde, de tal modo que os superiores dos superiores se tornam anônimos, misteriosos, sem face ou identidade, o que dá uma dimensão aterrorizante e enigmática aos inferiores. O poder torna-se sem rosto, mas também sem governança no excessivo da burocracia. Mais que isso, se apresenta como desumano, impessoal e acéfalo e de aparência monolítica, impermeável, hermeticamente consolidado, cristalizado e paralisado; revela uma organização que não existe, mas o mistério havido, funda o medo e abre o caminho para a opressão.

Olho Duro havia juntado ao relatório 24 anexos de "diversos testemunhos e depoimentos". O assunto fora a confusão ocorrida na entrada de um supermercado, antes mesmo que as portas se abrissem. Tudo era para que o Camarada Inspector, autoridade acima dele, pudesse decidir e deliberar os desdobramentos de uma ação do Estado frente ao ocorrido, ficando aberta a questão para novas investigações. O narrador, Olho Duro, relata que a fila para a compra do bacalhau fora formada logo cedo, antes da abertura do supermercado, e muitos dos lugares da fila que se já se formava, tinham sido demarcados com pedras, antes da meia-noite, portanto na véspera. Crianças que deveriam estar na escola, haviam também chegado mais cedo. No tempo certo seriam substituídas por adultos das famílias das quais pertenciam. Estas crianças, alunos e alunas, geraram problemas por se ausentarem da escola pública. Até mesmo o diretor acabou por ser chamado pelas autoridades para prestar depoimento, embora ele mesmo não estivesse na fila. Quanto às pedras que demarcavam o lugar, o problema foi que as pessoas que iam chegando, as empurravam para trás, rumo ao fim da fila, e as mamãs, que queriam comprar o bacalhau mais barato para vendê-lo com lucro nos bairros nobres, e que haviam colocado as pedras no dia anterior, se deram por prejudicadas. A confusão popular acabou por explodir quando um cão se meteu entre as pessoas da fila. E a briga começou.

Esse é o início do enredo. 
Nas palavras de Pepetela:

Quando as portas iam abrir, um cão de raça pastor-alemão que por ali passava, também se meteu na bicha (...). Ao cheirar uma das mulheres que se sentia prejudicada, o cão recebeu um pontapé e um enxotanço. Ele recuou e a dona do tijolo empurrando avançou para fora. Com o avanço lateral, a senhora ficou fora da bicha e os que estavam atrás aproveitaram avançar e tapar logo o lugar vazio. Ela quis voltar ao seu sítio na bicha, no momento preciso em que se abriam as portas. A força que vinha do fundo da bicha a empurrar a impediu de voltar ao lugar. Então começou a pancadaria pois a suposta lesada (segundo as suas próprias declarações) agrediu um homem que antes estava mesmo atrás dela. O homem respondeu à violência, as outras mulheres envolveram-se e aí estalou a maka. Praticamente nenhum componente da bicha escapou, voluntária ou involuntariamente, de entrar na maka. O supermercado teve que encerrar de novo as portas... (p. 141/2).

Olho Duro relata então que a polícia fora chamada, tendo sido feita a detenção de 23 mulheres e um homem. Por fim encerra a parte descritiva do relatório afirmando:

A Martal só abriu às 12 (doze) horas, depois de se autorizar a reabertura e constatar-se que o mujimbo era falso, pois infelizmente não havia nenhum bacalhau para vender, o que lamento ter de informar ao Cda Inspector, conhecido apreciador do produto. (142).

\section{B. Concluindo}

1. É mau o sistema de pedras e tijolos que nunca ficam devidamente identificados;

2. O culpado é a especulação que grassa e faz com que as mamãs lutem por bacalhau que não existe para depois o revenderam às donas de casa do Alvalade;

3. É difícil apurar as responsabilidades, pois faltam testemunhos preciosos e os que há são contraditórios e alguns nitidamente mentirosos. Mas quais?

4. O cão não teve culpa. Parece mesmo ser o único "inocente" provado. Mesmo que fosse culposo, não foi detido e ninguém mais o viu. 


\section{Propondo}

Em função das conclusões tiradas em B, permito propor ao criterioso julgamento do Camarada Inspector as seguintes propostas, a primeira de execução imediata e as duas seguintes para subirem a quem de direito:

1. Que se dê por encerrado o incidente da Martal, pois não houve vítimas a lamentar;

2. Que se combata o mujimbo através de todos os meios, para que cenas tão lamentáveis não voltem a se produzir;

3. Que se faça uma lei a definir se, na sociedade socialista, pedra e tijolo servem ou não para marcar lugar na bicha.

Luanda, aos 27 de abril de 1980 - ANO DO $1^{\circ}$. CONGRESSO EXTRAORDINÁRIO DO PARTIDO E DA CRIAÇÃO DA ASSEMBLEIA DO POVO.

Agente de Serviço, ass. DIAS (OLHO DURO)" (p. 141/2)

A crônica possui um jocoso trágico. É uma mostra das contradições na formação da sociedade urbana pós-colonial. Não se trata apenas de um processo de engessamento político, que evidentemente se dava como realidade histórica. Vai mais longe. A leitura é cultural, das ruas, do povo, do cotidiano recrudescido e fechado, sem horizonte ou perspectiva de uma superação. Se o estado antecipava a utopia e a transformava em um Império sem criatividade, o cotidiano se desfazia no insignificante, na luta frenética pelo nada. O Império soçobrava sob o signo da ineficiência, burocracia facilitadora de corrupção e cargos criados com nomenclaturas que exploram a possível beleza e grandiosidade da função, mas que se constituem em politicagem, oportunismo, desumanidade e exploração, ao mesmo tempo em que nada contribuíam para a dinamização da vida.

O cão, tomado de forma simbólica, é a personagem que mantém a liberdade criativa, mesmo que isso represente a ausência de sonho ou reconstrução social. O papel do sistema recrudescido na organização estatal, ao perder a capacidade de reencontrar o que motivou a luta pela libertação, retorna ao estágio inicial com protagonistas ocultos, e aproveitadores anônimos, por detrás da abstração institucional. Reserva-se a este institucional o perder-se sem rosto. Este, por sua vez, 
reduz-se a observador, como parte de um sistema que se reproduz, ao mesmo tempo em que sufocam os que criativamente poderiam desejar o redimensionar, restabelecer e traçar por outras vias, um novo sonho de liberdade. Ao perder historicamente a capacidade de reinventar a história, ou na tentativa de resolver e suplantar a ambiguidade da vida pelo regime da força, o resultado que emerge é o da ameaça de autodestruição de toda a sociedade.

O agente Olho Duro personifica o carnavalesco, o exagero da finitude não-utópica, o endurecimento hierárquico de governança focada no autoritarismo que se volta contra si, tornado monolítico, concebendo-se à nova sociedade pós-libertação como se fosse o final da história, mas o resultado é o trágico. A personagem é sem criatividade, senso de inutilidade e faz parte de uma máquina farta em benefícios para alguns, sustentados como uma grande família partidária em cumplicidade, cujos trâmites são denunciados profeticamente por Pepetela como socialismo esquemático.

Neste caso, há um pretenso rompimento entre o estágio do Império atualizado e a história que, como causa, se deu no interior do movimento libertador. Segundo Tillich, a ameaça da autodestruição ocorre pelo retorno ao início, quando a liberdade criativa se faz como voz profética, e o Império realizado é ameaçado pelos mesmos motivos que levaram à queda do anterior. Torna-se necessário a retomada da liberdade criativa, justamente esta observada, combatida, punida e banida pelo autoritarismo que se degrada.

Pepetela dá voz ao que não é importante, a um sistema fadado ao controle e à fatal descrença nos resultados de uma geração que sonhou, e lutou, pela utopia. Um simples cão, na condição de profeta, inteligência criativa, anônimo, desconhecido, expõe o lamento da história, numa espécie de grotesco melancólico, desencantado, cômico e triste.

\section{Notas inconclusas}

O diálogo proposto por Tillich entre a religião e a cultura, ou mais precisamente no nosso caso, diálogo entre a teologia e a literatura, não pode ser dado em termos da metáfora "nível". Nível, para Tillich, seria a fixação de uma hierarquia de controle de uma sobre a outra, da literatura à teologia, ou da teologia à literatura. Tillich prefere a expressão desta 
relação como "dimensões", "esfera” ou "graus". (2014, p. 478/9). O "nível” faria desaparecer a ambiguidade. Isto quer dizer que o discurso narrativo de Pepetela, ao tratar do rumo sem rumo da história angolana enclausurada, dialoga como expressão teológica e cultural. Evidencia a tentativa de por fim às ambiguidades, o que sempre acontece em sistemas revolucionários: estes se tornam monolíticos e se interpretam como o ápice da história. Será preciso retomar o símbolo "Reino de Deus" como busca, potência e superação na autotranscendência. Tillich por um lado e Pepetela pelo outro, ou pelo mesmo, compreendem que as ambiguidades da vida só poderão, ou serão superadas, numa dimensão maior que as possa abarcar. E o rumo é dinamizado, orientado e mediado pela retomada da voz profética, da qual o romancista faz parte.

$\mathrm{O}$ viés jocoso do discurso, em todas as crônicas de "O cão e os caluandas", intui uma fina ironia para apontar os caminhos da atualização histórica no finito, como se infinito fosse, Tillich chama isso simbolicamente de Império. A possível irrupção do kairós, não como possibilidade, mas finitude, consolidou de maneira monolítica em Angola, os sonhos havidos no processo de libertação. A instauração do regime autoritário, burocrático e corrupto, destruiu, e destrói, repetiu, e repete, os males contra os quais o próprio sistema havia se colocado em guerra para os banir. O centralismo colaborativo entre interesses de grupos e famílias específicas, afasta, suspende ou então inibe a liberdade criativa, necessária à permanência do vislumbre utópico como horizonte. Manifesta-se assim a distopia, ou a autodestruição. A finitude, lócus da existência histórica, é tida como infinitude, lócus da idealização e perfeição, e o que resta é o demônico, sem a dinâmica de reconstrução em face do controle do regime militarizado, fundamentado na força e na imposição do silêncio e obediência.

A narrativa crítica de Pepetela nos oferece um mapeamento existencial, o deslocamento da utopia à distopia, e como facilmente, na reorganização social e histórica de Angola, isso acabou por acontecer. Seu traçado e análise, que não somente dialoga com o poder ou com o socialismo esquemático, problematiza a própria cultura como, não apenas cooptada pelo sistema, mas como geradora do processo social que põe fim aos sonhos, trazidos para a finitude, como se esta infinitude fosse. Ou seja, o sujeito oprimido colabora com a opressão e, inge- 
nuamente (talvez nem tanto), também conscientemente se corrompe, assumindo como prática de vida o que deveria combater. Com o controle e supressão da voz profética, combativa e denunciadora, por consentimento ou imposição, o que resta é o fim do encanto. E sem a dialética da autocriatividade, a renovar os processos sociais e, por conseguinte, sem a autotranscendência para a superação história como vislumbre do símbolo "Reino de Deus" (Tillich), o resultado é a destruição.

E o romancista escreve e sonha, profetiza, diverte e entristece em sua ironia melancólica, ou alegria doída. Ao encerrar o romance, "O cão e os caluandas", com um paralelismo nas duas últimas crônicas, Pepetela convida o leitor, que primeiramente é angolano, e secundariamente também, a repensar e ter a fala para o onde caminha a história de seu povo:

Agora leitores, na minha escrita que morre começa a vossa fala.

$[\ldots]$

E o meu sonho... se foi. Com ele começa a vossa fala. (p. 164 e 169)

Da escrita para a fala. Do sonho para a fala. Literatura (escrita), religião (sonho) e, nos dois casos, a ambiguidade do movimento dinamizador pela voz profética (a fala); e quem fala é o povo.

\section{Referências}

BAKHTIN, Mikhail. A cultura popular na Idade Média e no Renascimento: o contexto de François Rabelais. 7ª ed. São Paulo: Hucitec, 2010.

CHAVES, Rita; MACÊDO, Tania (orgs). Portanto...Pepetela. São Paulo: Ateliê Editorial, 2009.

HEIDEGGER, Martin . Sein und Zeit. Tübingen: Max Niemeyer, 1967.

PEPETELA. A geração da utopia. Luanda: Textos Editores, 2013.

. A gloriosa família. Luanda: Textos Editores, 2016a.

. Jaime Bunda agente secreto. Luanda: Textos Editores, 2010b.

$2010 \mathrm{a}$. . Jaime Bunda e a morte do americano. Luanda: Textos Editores, . Muana Puó. Luanda: Textos Editores, 2016b.

. O quase fim do mundo. Luanda: Textos Editores, 2010. 
PIEPER, Frederico. Diálogos possíveis: As ambiguidades da vida em Paul Tillich e Ingmar Bergman. Correlatio. São Bernardo, v. 16, n. 1, pp 259-289, ISSN 1677-2644, junho de 2017.

TILLICH, Paul. Le Socialisme, Christianisme et Socialisme, Écrits socialistes allemands (1919-1931), Les Éditions du Cerf, Éditions Labor et Fides, Les Presses de l'Université Laval, 1992, p. 346.

Teologia da cultura. São Paulo: Fonte Editorial, 2009.

. Substance catholique et principe protestant. Paris/Genève/

Quebec: Éditions du Cerf, Éditions Labor et Fides, Université Laval, 1996.

Teologia sistemática. $7^{\text {a }}$. ed. São Leopoldo: Sinodal, 2005. 